\title{
Prostodonti klinik havasının mikrobiyal düzeyi üzerine havalandırma-klima sisteminin etkisi ${ }^{*}$
}

\author{
Murat Yenisey(0000-0003-2242-1482) ${ }^{\alpha}$, Ertan Emek Onuk(0000-0001-7643-046X) ${ }^{\beta}$, Nergiz Uz Rona(0000-0001-8101-3599) ${ }^{\gamma}$, \\ Şafak Külünk(0000-0002-3435-470X) ${ }^{\alpha}$, Gözlem Ceylan(0000-0003-1257-803X) ${ }^{\alpha}$, Ahmet Umut Güler(0000-0002-9298-0362) ${ }^{\wedge}$,
}

Selcuk Dent J, 2019; 6: 280-285 (Doi: 10.15311/selcukdentj.316885)

\section{öz}

Prostodonti klinik havasının mikrobiyal düzeyi üzerine havalandırma-klima sisteminin etkisi

Amaç: Prostodonti kliniği havasının mikrobiyolojik kalitesi üzerine havalandırma-klima sisteminin etkisinin ortaya konulmasıdır.

Gereç ve Yöntemler: Bioaerosol örnekler Ondokuz Mayıs Üniversitesi, Diş Hekimliği Fakültesi, Protez kliniğinden toplanmıştır. Havalandırma sistemi toplam $7485 \mathrm{~m}^{3} / \mathrm{s}$ havalandırma kapasitesine sahiptir. Bu sisteminin etkinliğinin değerlendirilmesi amacıyla, havalandırma sistemi kapatılarak, klinik gün boyu rutin çalışmasına devam etmiştir. Gün sonunda ise toplam mezofilik aerobik bakteri ve mantar sayısının belirlenmesi amacıyla ayrı ayrı 10'ar örnek toplanmıştır. Bu örneklemeden sonra, aynı işlem havalandırma sistemi gün boyunca çalıştııımış ve gün sonunda aynı şekil ve sayıda örnekleme yapılmıștır. Hava örneklemesinde MAS 100 (Merck, Germany) hava örnekleme cihazı kullanılmıştır. Her 15 günde bir akşam ve sabah olmak üzere toplamda 12 dönemde 480 örnek alınmıştır. Toplam mezofilik aerobik bakteri sayısının belirlenmesinde Nutrient Agar, toplam mantar sayısının belirlenmesinde ise \% 1 Penisilin içeren Sabouraud Dekstroz Agar kullanıımıştır. Alınan örnekler sırasıyla $35^{\circ} \mathrm{C}$ 'de $48-72$ saat ve $25^{\circ} \mathrm{C}$ 'de 5 gün inkubasyona bırakılmıştır. İnkubasyon sonrası oluşan koloniler sayılarak metreküpteki bakteri ve mantar sayıları koloni oluşturma ünitesi $\left(\mathrm{CFU} /{ }^{\mathrm{m} 3}\right)$ şeklinde ifade edilmişlerdir. Sonuçların istatiksel olarak hesaplanmasında Feller doğrulaması kullanılmıştır. Elde edilen veriler student $T$ testi ile değerlendirilmiştir. Analizler SAS 9.01 istatistik paket programında yapılmışıı.

Bulgular: Havalandırma siteminin kapalı ve açık olduğu durumda hem toplam aerobik mezofilik bakteri, hem de toplam mantar sayılarında istatistiksel olarak anlamlı ölçüde $(p<.0001)$ değişim gözlenmiştir. Gözlenen farklılık azalma yönündedir.

Sonuç: Diş kliniklerinde havanın mikrobiyolojik kalitesini kontrol etmek ve hekimler ve hastalar için enfeksiyon riskini azaltmak için kliniklerde yapısal olarak etkin önleyici önlemlerin alınması ve bu amaçla standartların oluşturulması gereklidir.

\section{ANAHTAR KELIMELER}

Havanın mikrobiyolojik örneklemesi, mantar, mezofilik bakteri, prostodonti kliniği

\section{ABSTRACT}

Effect of ventilation-air conditioning system on the microbial level of prosthodontics clinic air

Background: Aim of this study is to evaluate the effect of the ventilation-air conditioning system on the microbiological quality of the air of the prosthodontic clinic.

Methods: Bioaerosol specimens were collected from Ondokuz Mayıs University, Faculty of Dentistry, Prosthodontics Clinic. The ventilation system has a total ventilation capacity of $7485 \mathrm{~m}^{3} / \mathrm{s}$. In order to assess the effectiveness of this system, the ventilation system was switched off and continued routine day-to-day clinical practice. At the end of the day, 10 specimens were collected separately to determine the total number of mesophilic aerobic bacteria and fungi. Ventilation system was run throughout the day and at the end of the day the same shape and number of samples were made after this sampling by same manner, MAS 100 (Merck, Germany) air sampler was used in the air sampling. 480 samples were collected in 12 periods in total every 15 days, one in the evening and one in the morning. Nutrient Agar was used to determine the total number of mesophilic aerobic bacteria and Sabouraud Dextrose Agar containing $1 \%$ Penicillin was used to determine the total number of fungi. The samples were allowed to incubate for $48-72$ hours at $35^{\circ} \mathrm{C}$ and 5 days at $25^{\circ} \mathrm{C}$, respectively. The colonies formed after incubation were counted and the number of bacteria and fungi on the meter were expressed as colony forming unit $\left(\mathrm{CFU} / \mathrm{m}^{3}\right)$. Feller verification was used for the statistical calculation of the results. The obtained data were evaluated by student T test. Analyzes were made in SAS 9.01 statistical package program.

Results: When the ventilation system was closed and open, there was a statistically significant change $(p<.0001)$ in total aerobic mesophilic bacteria and total fungus numbers. The difference observed is the decrease.

Conclusion: To control the microbiological quality of the air in dental clinics and to reduce the risk of infection for physicians and patients, structurally effective preventive measures should be taken in clinics and establishing standards for this purpose.

\section{KEYWORDS}

Microbiological sampling of air, fungus, mesophilic bacteria, clinic of prosthodontics

\footnotetext{
* Ondokuz Mayıs Üniversitesi DHFO48 numaral BAP projesi ile desteklenmiștir ve "34th Annual Conference of the European Prosthodontic Association $\& 1$ st Conference of the Association of Prosthetic Dentistry of Kosovo" isimli konferansta poster olarak sunulmuștur.

${ }^{\alpha}$ Ondokuz Mayıs Üniversitesi Diş Hekimliği Fakültesi Protetik Diş Tedavisi Anabilim Dalı, Samsun

$\beta$ Ondokuz Mayis Üniversitesi Veteriner Fakültesi Klinik Öncesi Bilimler Bölümü, Samsun

${ }^{\gamma}$ Sağlık Bakanlığı Bafra Ağız Diş Sağlığı Merkezi, Bafra, Samsun

${ }^{\lambda}$ Özel MedicaDent Ağız ve Diş Sağlığı Polikliniği Kadıköy, İstanbul
} 
Ağız boşluğu bakterilerin üremesi için oldukça elverişli bir besi yeridir. Yapılan araştırmalarda ağız hijyeni zayıf bir hastanın $1 \mathrm{~mm}^{3}$ 'lük tükürüğünde 6 milyon mikroorganizma bulunduğu bildirilmiştir. ${ }^{1}$ Diş hekimliğinde kullanılan cihazlar ve çalışma ortamı, patojenlerin yayılması için bir araç rolü üstlenmektedir. Patojenlerin geçişi primer olarak eller ve kullanılan aletlerle temasın yanı sıra, tükürük ve kanın sıçramasıyla gerçekleşmektedir. Dental işlemler esnasında bakteriyel aerosol seviyesi oldukça artar. Tedavi işlemlerinde ortaya çıkan aerosoller ve ağızdaki bakteriler, dental kliniğin çalışma sahasına daha fazla yayılmaktadır. Yapılan çalışmalarda tedavi ișlemlerinin yapıldığı odada veya çok ünitli kliniklerin merkezinde kalan unit çevresinde aerosol konsantrasyonunun en yüksek düzeyde olduğu saptanmıştır. ${ }^{2}$ Enfektif hastalık riski yüksek hastaların (HIV, HBV, HBC, HBD, TBC (+) taşıyıcıları vs.) fakülteye kabullerinde belirli testlerle tespit edilmesi belki de taşıyıcıların saptanmasında ve çapraz kontaminasyonun engellenmesinde en önemli yöntemdir. Ortama yayılan aerosol miktarı dental tedavi işlemlerinin türüyle ve kullanılan cihazlarla ilgilidir. Yüksek devirli el aletleri ve ultrasonik scalerlar kullanıldığı zaman havaya yayılan aerosol miktarı oldukça artmaktadır. $^{3}$ Dental işlemler sırasında ortamdaki bakteriyel kontaminasyonun en büyük kaynağının ağız boşluğu olmasının yanı sıra dental ünitlerde kullanılan suyun da kontaminasyondaki payı büyüktür. Unit suları potansiyel bir enfeksiyon kaynağı olabilmektedirler. Dental aerosollerden korunmak için hastaya işlem öncesi antiseptik gargaralar kullandırabilir. Bir başka çözüm ise ünit doz sisteminin benimsenmesi, rubber dam uygulanması, maske, eldiven, gözlük, yüksek emiş gücündeki ağız aspiratörlerinin kullanımı gibi bariyer tedbirlerin rutinde hastalar ve hekim tarafından uygulanmasıdır. ${ }^{4,5}$ Bununla birlikte etkin hava temizleme sistemleri ve klimalar, ultraviole ışık kullanımı, yüksek emiş gücü bulunan aerosol emici cihazların ve etkili yüzey dezenfektanlarının rutin kullanımı da önerilmektedir. 6,7,8,9,10
Literatür incelemesi yapıldığında ülkemizde konu ile ilgili araştırmaların sınırlı olduğ $u^{11,12}$ ve yeni kurulacak kliniklerde kullanılması gerekli havalandırma sistemi bileşenleri, kapasitesi ve uygunluğu konusunda yeterli bilginin olmadığı görülmektedir. Bu amaçla; havalandırma-klima sistemi uluslar arası standartlara göre ayarlanmış, aletler için rutin sterilizasyonun ve yüzeyler için kimyasal sterilizasyon (dezenfeksiyon) işlemlerinin doğru yapıldığı, kimyasal sterilizasyon ve UV sterilizasyonuna uygun ünit sistemlerinin kullanıldığı optimal şartlara sahip bir klinik ortamda havadaki bakteriyel ve fungal kontaminasyonun saptanması ve havalandırmaklima sistemi kapatıldı̆ı zamanki klinik ve laboratuar ortamı ile karşılaştıııması hedeflenmiştir. Çalışmamızın hipotezi klinik havalandırma- klima sisteminin bakterial- fungal kolonizasyonu azaltacağı şeklindedir.

\section{GEREÇ VE YÖNTEM}

\section{Örnekleme yeri ve özellikleri}

Bioaerosol örnekler Ondokuz Mayıs Üniversitesi, Diş Hekimliği Fakültesi, Protez kliniğinden toplanmıştır. Protetik diş tedavisi kliniği diş hekimliği fakültesinin ana binasının 3. katında olup içerisinde toplam 17 adet çalışma birimi bulunmaktadır ve yüzey alanı 203,80 $\mathrm{m}^{2}$ 'dir. Kliniğin havalandırılması bir merkezden çıkan ve farklı 3 ana kola ayrılan $40.000 \mathrm{~m}^{3} / \mathrm{s}$ emiş hızına sahip merkezi bir aspiratör ile gerçekleştirilmektedir. Bu kollardan ilk ikisi 1. katta bulunan iki farklı preklinik laboratuvarına, üçüncüsü ise 3 . katta bulunan protez kliniğine girmektedir. Protez kliniğine giren 3 . ana kol 12 bölüme ayrılarak emiş pencereleri kliniğin farklı noktalarına yerleştirilmiştir. Protez kliniğinin havalandırma sistemi toplam $7485 \mathrm{~m}^{3} / \mathrm{s}$ havalandırma kapasitesine sahiptir (Şekil 1).

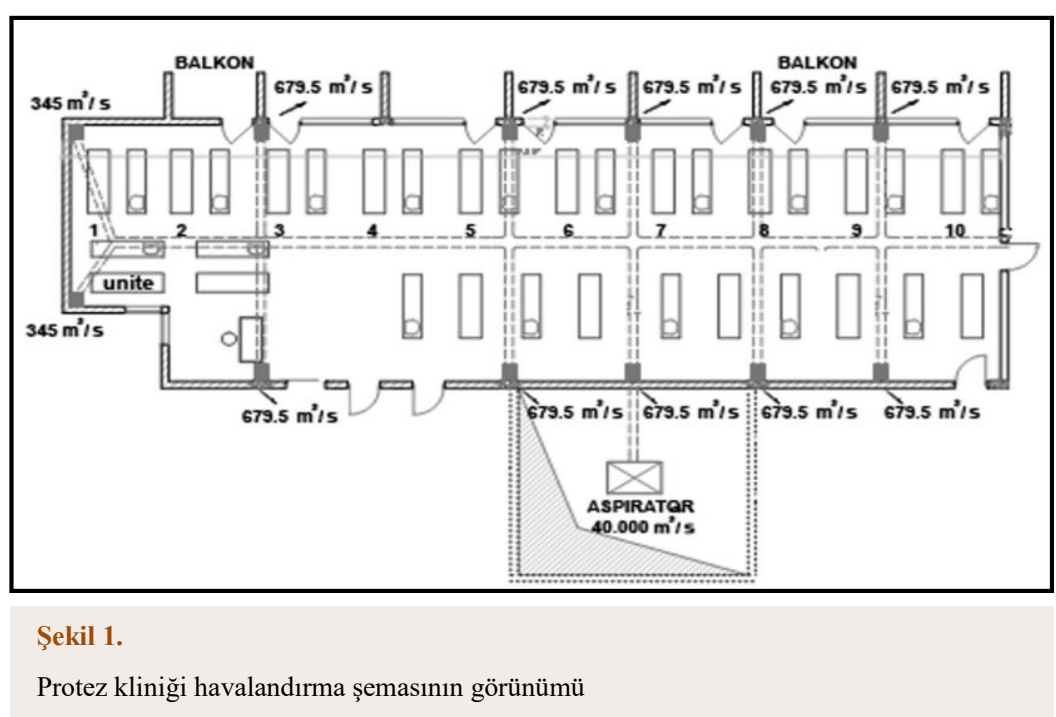

\section{Örneklerin toplanması}

Çalışmada, protetik diş tedavisi kliniğinden her 15 günde bir olmak üzere toplam 12 örnekleme yapıldı. Çalışmada bir dönem için havalandırma sistemi açık ve kapalı olmak üzere toplam 40 olmak üzere 12 dönemde 480 örnek alındı. Klinik havalandırma sistemi bir proje kapsamında hazırlandığı için fakültemizin diğer kliniklerinde mevcut değildir. Normal hava kalitesinin ve havalandırma sisteminin 
etkinliğinin değerlendirilmesi amacıyla, havalandırma sistemi kapatılarak, klinik gün boyu rutin çalışmasına devam etmiştir. Gün sonunda ise toplam mezofilik aerobik bakteri ve mantar sayısının belirlenmesi amacıyla önceden belirlenen 10 adet diş ünitine, hekimin çalışma pozisyonunu etkilemeyecek şekilde yaklaşık $5 \mathrm{~m}^{2}$ ' lik her bir ünit için ayrılan alanda, hastanın baş pozisyonundan 0,5 m uzaklığa $^{25}$ standart olarak belirlenen bölgelerden her biri için 1'er adet örnekleme yapıldı. Bu örneklemeden sonra aynı örnekleme işlemi havalandırma sistemi açıkken tekrarlandı. Böylece havalandırma sisteminin etkinliği ortaya konuldu.

Toplam mezofilik aerobik bakteri sayısının belirlenmesinde Nutrient Agar (NA) kullanıldı. Alınan örnekler $35^{\circ} \mathrm{C}$ 'de $48-72$ saat inkubasyona bırakıldı ve inkubasyon sonrası oluşan koloniler sayıldı.

Toplam mantar sayısının belirlenmesinde $\% 1$ Penisilin içeren Sabouraud Dekstroz Agar kullanıldı. Alınan örnekler $25^{\circ} \mathrm{C}$ 'de 5 gün inkubasyona bırakıldı ve inkubasyon sonrası oluşan koloniler sayıldı.

\section{Örnekleme cihazı}

Hava örnekleri MAS-100Eco ${ }^{\mathrm{TM}}$ (Merck, Almanya) hava örnekleme cihazı kullanılarak toplandı. MAS-100Eco ${ }^{\mathrm{TM}}$, havayı 400 delikli bir sıkıştırma plağına tek yönde aspire ederek örneklemektedir. $1 \mathrm{~mm}$ veya daha küçük partikül büyüklüğüne sahip aspire edilmiş hava, doğrudan cihaz içine yerleştirilmiş $90 \mathrm{~mm}$ çapındaki petri kutusuna yönlendirilmektedir. Cihaz 100 L/dk'lık bir akış hızı oranı ile havayı sıkıştırmakta ve bu oran Andersen örneklemesinde 5. seviyeye karşılık gelmektedir. ${ }^{15}$ Her toplama periyodunda, petri kutuları uygun sıcaklıkta inkube edilerek oluşan koloniler sayılarak ve her metreküpte koloni oluşturma ünitesi (Colony Forming Units-CFU) şeklinde ifade edildi $\left(\mathrm{CFU} / \mathrm{m}^{3}\right)$. Sonuçların istatiksel olarak hesaplanmasında Feller doğrulaması kullanıldı. Analizler SAS 9.01 istatistik paket programında student $T$ test kullanılarak yapıldı.

$\operatorname{Pr}=\mathrm{N}[1 / \mathrm{N}+1 / \mathrm{N}-1+1 / \mathrm{N}-2 \ldots \ldots \ldots \ldots . . \mathrm{N}-\mathrm{r}+1]$

$\mathrm{Pr}=$ olası istatistikler toplamı, $\mathrm{N}=$ Örnekleme kafasındaki toplam delik sayısı $(=400), R=$ Koloni sayısı

Petri kutularında sayılan koloniler (CFU) ile toplanan havadaki bioaerosol miktarı aşağıdaki bağıntı ile ilişkilendirilmiştir.

$$
\left[\mathrm{CFU} / \mathrm{m}^{3}\right]=[\mathrm{CFU}] \text { Petri } \times(1000 / \mathrm{VS}) \text {. }
$$

\section{BULGULAR}

Çalışma dönemi boyunca ortam havasında bulunan toplam mezofilik bakteri ve mantar miktarlarının saptanabilmesi amacıyla havalandırma sisteminin açık ve kapalı olduğu şartlar altında 12 kez örnekleme yapılmış ve bu süreçte alınan toplam 480 örneğe ait veriler, ortalamalar ve standart sapmalar Tablo 1 ve Tablo 2'de verilmiştir.

\section{Tablo 1.}

\section{Havalandırma-klima sistemi kapalı ve açık iken elde edilen toplam mezofilik aerobik bakteri $\left(\mathrm{cfu} / \mathrm{m}^{3}\right)$ düzeyleri}

\begin{tabular}{|c|c|c|c|c|c|c|c|c|c|}
\hline \multirow{2}{*}{$\begin{array}{l}\text { Ölçüm } \\
\text { grupları }\end{array}$} & \multicolumn{3}{|c|}{ Havalandırma kapalı } & \multicolumn{3}{|c|}{ Havalandırma açık } & \multicolumn{3}{|c|}{ Fark } \\
\hline & $\mathbf{N}$ & Mean & $\begin{array}{l}\text { Standart } \\
\text { Hata }\end{array}$ & $\mathbf{N}$ & mean & $\begin{array}{l}\text { Standart } \\
\text { sapma }\end{array}$ & $\mathbf{N}$ & mean & $\begin{array}{l}\text { Standart } \\
\text { sapma }\end{array}$ \\
\hline 1 & 10 & 1382.00 & 78.40 & 10 & 277.00 & 32.29 & 10 & 1105.00 & 102.59 \\
\hline 2 & 10 & 1514.00 & 88.40 & 10 & 446.00 & 47.31 & 10 & 1068.00 & 117.47 \\
\hline 3 & 10 & 1884.00 & 96.94 & 10 & 571.00 & 41.35 & 10 & 1313.00 & 108.76 \\
\hline 4 & 10 & 1635.00 & 97.76 & 10 & 295.00 & 21.72 & 10 & 1340.00 & 94.22 \\
\hline 5 & 10 & 1046.00 & 166.67 & 10 & 181.00 & 16.70 & 10 & 865.00 & 169.97 \\
\hline 6 & 10 & 1044.00 & 145.33 & 10 & 294.00 & 21.72 & 10 & 750.00 & 144.31 \\
\hline 7 & 10 & 1407.00 & 130.17 & 10 & 377.00 & 27.29 & 10 & 1030.00 & 134.15 \\
\hline 8 & 10 & 1303.00 & 50.62 & 10 & 376.00 & 23.53 & 10 & 927.00 & 54.65 \\
\hline 9 & 10 & 1228.00 & 92.21 & 10 & 282.00 & 22.20 & 10 & 946.00 & 97.21 \\
\hline 10 & 10 & 1164.00 & 234.06 & 10 & 202.00 & 18.37 & 10 & 962.00 & 218.94 \\
\hline 11 & 10 & 1735.00 & 154.45 & 10 & 341.00 & 45.37 & 10 & 1394.00 & 165.75 \\
\hline 12 & 10 & 1383.00 & 109.90 & 10 & 293.00 & 17.77 & 10 & 1090.00 & 112.88 \\
\hline Toplam & 120 & 1393.75 & 42.39 & 120 & 327.92 & 12.41 & 120 & 1065.83 & 40.58 \\
\hline
\end{tabular}

Tablo 2.

Havalandırma-klima sistemi kapalı ve açık iken elde edilen toplam mantar (cfu/m³) düzeyleri

\begin{tabular}{|c|c|c|c|c|c|c|c|c|c|}
\hline \multirow{2}{*}{$\begin{array}{l}\text { Ölçüm } \\
\text { grupları }\end{array}$} & \multicolumn{3}{|c|}{ Havalandırma kapalı } & \multicolumn{3}{|c|}{ Havalandırma açık } & \multicolumn{3}{|c|}{ Fark } \\
\hline & $\mathbf{N}$ & mean & $\begin{array}{l}\text { Standart } \\
\text { Hata }\end{array}$ & $\mathbf{N}$ & mean & $\begin{array}{l}\text { Standart } \\
\text { sapma }\end{array}$ & $\mathbf{N}$ & mean & $\begin{array}{l}\text { Standart } \\
\text { sapma }\end{array}$ \\
\hline 1 & 10 & 402.00 & 35.83 & 10 & 84.00 & 9.80 & 10 & 318.00 & 32.41 \\
\hline 2 & 10 & 321.00 & 23.78 & 10 & 81.00 & 8.23 & 10 & 240.00 & 24.13 \\
\hline 3 & 10 & 207.00 & 16.33 & 10 & 70.00 & 7.30 & 10 & 137.00 & 12.39 \\
\hline 4 & 10 & 313.00 & 51.73 & 10 & 83.00 & 8.31 & 10 & 230.00 & 48.49 \\
\hline 5 & 10 & 240.00 & 19.67 & 10 & 73.00 & 8.03 & 10 & 167.00 & 43761 \\
\hline 6 & 10 & 182.00 & 18.25 & 10 & 74.00 & 9.33 & 10 & 108.00 & 23.13 \\
\hline 7 & 10 & 315.00 & 35.19 & 10 & 82.00 & 8.91 & 10 & 233.00 & 37.30 \\
\hline 8 & 10 & 164.00 & 15.14 & 10 & 59.00 & 5.04 & 10 & 105.00 & 13.76 \\
\hline 9 & 10 & 417.00 & 12.57 & 10 & 90.00 & 8.7 & 10 & 327.00 & 18.20 \\
\hline 10 & 10 & 242.00 & 22.60 & 10 & 78.00 & 8.27 & 10 & 164.00 & 23.63 \\
\hline 11 & 10 & 244.00 & 15.14 & 10 & 98.00 & 4.16 & 10 & 146.00 & 14.40 \\
\hline 12 & 10 & 384.00 & 24.91 & 10 & 104.00 & 11.37 & 10 & 280.00 & 32.90 \\
\hline Toplam & 120 & 285.92 & 10.50 & 120 & 81.33 & 2.53 & 120 & 204.58 & 10.15 \\
\hline
\end{tabular}


Akşam ve sabah ölçümlerinde hem bakteri hem de mantar sayılarında student $\mathrm{T}$ testi ile yapılan değerlendirmede istatistiksel olarak anlamlı ölçüde değişim gözlenmiştir $(p<.0001)$. Gözlenen farklıık bakteriyel ve mantar kolonizasyonunun havalandırma sistemi açıldığında azaldığını göstermektedir (Tablo 3 ve Tablo 4).

\section{TARTIŞMA}

Bioaerosoller, biolojik kökene sahip hava kökenli partiküllerin tamamına verilen isimdir. Klinik ortam havası bakteriler, mantarlar, mantar sporları, virüsler ve farklı antijenler içermektedir. Aerodinamik yapıdadırlar ve 0.5-100 mikron boyutlarındadırlar. Bu patojennonpatojen biyolojik etkenlerden bir ya da birkaçına veya onların metabolitlerine (endotoksin, mikotoksin) maruz kalmak olumsuz sağlık problemlerine ve enfeksiyonlara yol açabilir. Örnek olarak astım ataklarının artması ve bronşiyal hiperaktivitedeki artış bioaerosol miktarındaki artışla yakından ilişkilidir. 80 'den fazla mantar türünün solunum sistemi alerjileri ile ilişkili olduğu belirtilmiştir. ${ }^{10}$

Havanın mikrobiyolojik yönden örneklenmesinde çöktürme (sedimentasyon) ve sıkıştırma (impaction) metotları kullanılabilmektedir. Ancak sıkıştırma metodu ile önceden programlanmış bir hava örnekleyicisi ile örneklemenin yapılması bilinen bir hava hacmindeki mikroorganizma seviyesinin belirlenmesine olanak sağlamaktadır ve çöktürme metodu ile karşılaştırıldığında daha güvenilir sonuç vermektedir. Buna en önemli sebep olarak ise çöktürme metodu ile test edilen havanın miktarının tam olarak belirlenememesi gösterilmektedir. ${ }^{13}$ MAS-100Eco ${ }^{\text {TM }}$ (Merck, Germany) hava örnekleme cihazı Andersen tarafından tanımlanan delikleri olan üst kapak bölgesi içinden süzülen partikülleri de içeren havanın cihazın içerisindeki besi yeri üzerine belirlenen sürede ekim yapması esasına göre çalışır. ${ }^{14,15}$ Yapılan araştırmalarda MAS-100 Eco hava örnekleme cihazının pratikliği, taşınabilir olması sebebiyle gıda, boya, çevre mühendisliği ve tıbbi sektörde yaygın olarak kullanıldığı görülmektedir. ${ }^{16}$ Çalışmamızda cihazın tercih sebebi yapılan ölçümler arasında delikli kapak bölmesinin steril edilmeye elverişli olması, ek bir güç kaynağına intiyaç göstermeksizin kendi aküleri ile yaklaşık 10'ar dakikalı 25 ölçümün yapılabilmesine olanak vermesi, taşınabilir olması gibi etkenler yer almaktadır. Cihazdaki emiş süresi ve ekimi yapılan hava hacmi ile ilgili olarak istatistiksel işlemlerin doğru yapılabilmesini sağlayan Feller doğrulama skalasının bulunması ise diğer bir tercih sebebidir. Bununla beraber oftalmik cerrahi yapilan ortamda bulunan sağlık personelinin metreküp hava başına bakteriyel koloni ölçüm $\left(\mathrm{CFU} / \mathrm{m}^{3}\right)$ sonuçlarına etkisinin değerlendirildiği çalışmada kontaminasyon düzeyi aktif ve pasif olarak iki metotla değerlendirilmiş aktif yöntemde çalışmamızda da kullandığımız hava örnekleyici cihazın bir benzeri kullanılmış ve besi yeri üzerine direk ekim yapılmış, pasif yöntemde ise muhtelif yerlere yerleştirilen besi yerlerine pasif yöntemle belli süre zarfında ekim gerçekleşmiştir. Ekim- örnekleme işlemleri cerrahi sırasında yapılmıştır. Ve hem aktif hem de pasif örnekleme ile sağlanan sağlık personeli sayısı ile ilişkili $\mathrm{CFU} / \mathrm{m}^{3}$ koloni miktarlarının birbiri ile korelasyon gösterdiği aktif ya da pasif ölçüm yöntemlerinden birinin bu işlemlerde

\section{Tablo 3.}

\section{Bakteriyel kolonizasyon için havalandırmanın kapalı ve açık olduğu durumlar için student T test ile yapılan istatistiksel test}

\begin{tabular}{|c|c|c|c|c|c|c|c|c|c|c|}
\hline \multirow{2}{*}{ Difference } & \multirow{2}{*}{$\mathbf{N}$} & \multicolumn{3}{|c|}{ Havalandırma kapalı } & \multicolumn{3}{|c|}{ Havalandırma açık } & \multirow{2}{*}{$\begin{array}{l}\text { Standart } \\
\text { hata }\end{array}$} & \multirow{2}{*}{ t değeri } & \multirow{2}{*}{$\mathbf{P}$} \\
\hline & & Lower cl & Upper cl & Mean & Lower cl & Upper cl & mean & & & \\
\hline $\begin{array}{l}\text { Havalandırma } \\
\text { kapalı-açık }\end{array}$ & 120 & 985.48 & 1146.20 & 1065.80 & 394.54 & 509.21 & 444.55 & 40.582 & 26.26 & $<.0001$ \\
\hline
\end{tabular}

Tablo 4.

Mantar kolonizasyonu için havalandırmanın kapalı ve açık olduğu durumlar için Student T test ile yapılan istatistiksel test

\begin{tabular}{|c|c|c|c|c|c|c|c|c|c|c|}
\hline \multirow{2}{*}{ Difference } & \multirow{2}{*}{$\mathbf{N}$} & \multicolumn{3}{|c|}{ Havalandırma kapalı } & \multicolumn{3}{|c|}{ Havalandırma açık } & \multirow{2}{*}{$\begin{array}{l}\text { Standart } \\
\text { hata }\end{array}$} & \multirow{2}{*}{ t değeri } & \multirow[b]{2}{*}{$\mathbf{P}$} \\
\hline & & Lower cl & Upper cl & Mean & Lower cl & Upper cl & mean & & & \\
\hline $\begin{array}{c}\text { Havalandırma } \\
\text { kapalı-açık }\end{array}$ & 120 & 184.48 & 224.69 & 204.58 & 98.71 & 127,4 & 111.23 & 10.15 & 20.15 & $<.0001$ \\
\hline
\end{tabular}


kullanılmasının fark yaratmadığı, ihtiyaca göre ikisinin bir arada da uygulanabileceği vurgulanmıştır. ${ }^{24}$

Diş kliniklerindeki bakteriyel aerosol miktarları yapılan dental işlemler ile ilişkilendirilmektedir. Endodonti, periodonti ve prostodonti kliniklerinde tedavi esnasında ortaya çıkan bakteriyel aerosol miktarlarının belirlendiği bir çalışmada en yüksek aerosol düzeyinin prostodontik tedavi esnasında, en düşük miktarın ise endodontik işlemler esnasında oluştuğu gösterilmiştir. ${ }^{17}$ Benzeri bir çalışmada hava mikrobiyal kontaminasyon indexi değerinin endodontik tedaviler sırasında $0,5 \mathrm{~m}$ mesafedeki besiyerlerinde 10, 4 CFU/ $\mathrm{dm}^{2} / \mathrm{h}$ seviyelerinde olduğu, türbin kullanımının ve süresinin koloni değerleri üzerine istatistiksel olarak etkili olmadığı, koloni değerlendirmelerinde ise Micrococcus, Staphylococcus ve Streptococcus tiplerinin izole edildiği gösterilmiştir. ${ }^{25}$ Havalandırma- iklimlendirme sistemi farklı olmakla beraber çalışmamızda hava örneklerinden elde etmiş olduğumuz yüksek koloni değerleri protetik tedavilerdeki yüksek mikrobiyal hava kirlenmesini kontaminasyonunu doğrular niteliktedir.

Bir başka çalışmada da elde edilen bakteriyolojik sonuçlar tedavi prosedürü ile ilişkilendirilmiştir. $\mathrm{Bu}$ çalışmada 15 farklı klinikten toplanan 90 hava örneğinde toplam mezofilik bakteri sayısının klinik çalışmaya başlamadan önce ortalama $129 \mathrm{CFU} / \mathrm{m}^{3}$ olduğu 4 saatlik bir çalışma periyodundan sonra bu sayının 429,6 $\mathrm{CFU} / \mathrm{m}^{3}$ olduğu belirlenmiştir. Yine aynı çalışmada toplam mantar sayısının klinik aktivite esnasında 109.0 $\mathrm{CFU} / \mathrm{m}^{3}$ 'den $230.7 \mathrm{CFU} / \mathrm{m}^{3}$ 'e çıktığı yani iki kattan fazla arttığı ortaya konulmuştur. Özellikle ultrasonik scaling işlemi esnasında aerosol miktarlarının arttığı bildirilmiştir. ${ }^{18} \mathrm{Bu}$ çalışmada havalandırma-klima sisteminin kapalı olduğu dönemde toplam mezofilik bakteri sayısı ortalama $1393,75 \mathrm{CFU} / \mathrm{m}^{3}$, toplam mantar sayısı ise $285,92 \mathrm{CFU} / \mathrm{m}^{3}$ olarak belirlenmiştir. Havalandırma-klima sistemi aktif durumda iken bu miktarlarda üç kattan daha fazla bir düşüş gözlenmiş ve sırasıyla $285,92 \mathrm{CFU} / \mathrm{m}^{3}$ ve $81,33 \mathrm{CFU} / \mathrm{m}^{3}$ olarak belirlenmiştir. Çalışmamızda elde edilen aerosol miktarlarının Berlan ve ark. ${ }^{18}$ 'dan daha yüksek seviyede bulunmasının nedeninin çalışmanın sadece prostodonti kliniği ile sınırlandırımış olması ve kliniğimizde çokluünite (Multichair) sisteminin bulunması olabileceği düşünülmektedir. Yapılan bir çalışmada çoklu üniteye sahip kliniklerdeki total bakteriyel aerosol miktarının 5 kat daha fazla olduğunun saptanmış ${ }^{19}$ olması bu tezimizi desteklemektedir.

Çalışmamızda genel anlamda klinik havalandırma sistemi emiş bölgelerinin unit yerleşimine göre uygunluğunun ve emiş kapasitesinin değerlendirilmesi düşünüldüğü için sadece ortamdaki total bakteri ve mantar sayıları araştııımıştır. Havalandırma sisteminin çalıştırılığı ve kapatılığı durumlarda sistem açıkken total bakteri sayılarında istatistiksel olarak anlamlı derecede $(p<.0001)$ azalmanın olduğu gösterilmiştir. Yine aynı şekilde havalandırma-klima sisteminin açık olduğu durumda toplam mantar sayılarında istatistiksel olarak belirgin $(p<.0001)$ bir azalmanın olduğu görülmüştür. Literatürde diş kliniklerinde hava kalitesinin daha detaylı incelenmesine yönelik araştırmalara da rastlamak mümkündür. Bu tür bir çalışmada ortam ısısı, $\mathrm{CO}_{2}$ miktarı, ve bio aerosolller üzerinde çalışıımışıı ve havada asılı partikül ve $\mathrm{CO}_{2}$ konsantrasyonunun, özellikle, yoğun çalışılan saatlerde, uluslar arası standartlara göre yüksek olduğu gösterilmiştir. ${ }^{20,21}$ Başka bir çalışmada diş hekimliği kliniğinde mikrobiyal hava kirliliğini azaltmada iyonizasyonun etkinliğine bakılmıştır. $13.5 \mathrm{kV}$ gücündeki iyonizasyon jeneratörü bu amaçla kullanılmıştır. Havanın mikrobiyal seviyelerinde iyonizasyon jeneratörü çalıştııldığı zaman \% 40-50 düzeylerinde düşüş olduğu saptanmıştır. ${ }^{14}$ Bununla birlikte dental kliniklerde yapılan uygulamaların ortam havasında bulunan ortalama bakteri seviyesini dış ortama oranla yaklaşık 1.5 kat arttırdığı ve kliniklerde üretilen aeresol ve bioaerosol partiküllerine maruz kalmanın sağlık açısından önemli risk oluşturacağı bildirilmektedir. ${ }^{22}$ Hastanenin cerrahi ve yoğun bakım ünitesini kontrol eden Isitma, havalandırma ve iklimlendirme sistemlerinin hava kökenli patojenler tarafından kontaminasyonunun değerlendirildiği çalışmada havalandırma sistemin kalbi olan nem alma tekerleği denilen mekanizmanın kimyasal dezenfeksiyon yöntemleri ile dekontamine edilmesinin ortam havasındaki Aspergillus fumigatus miktarında belirgin (6 CFU/500 L) azalma sağladığı ve mikrobiyal anlamda daha temiz bir ortam havası için klima sisteminin belirli parçalarının düzenli olarak dezenfekte edilme gerekliliği vurgulanmıştır. ${ }^{23}$

Bu nedenle hastalar ve diş hekimleri için sağlık risklerini belirlemek ve en aza indirmek için kapsamlı çalışmaların yapılması gerekmektedir. Bu çalışma ile elde edilen verilere dayanılarak yoğun hasta trafiğine sahip, bioaerosol üretimi fazla olan tüm diş kliniklerinde ortamdaki çapraz kontaminasyonun engellenebilmesi veya mikrobiyal yükün azaltılabilmesi için kirli havanın dış ortama atıldığı yüksek emiş gücündeki havalandırma sistemlerinin, ya da alternatif olarak dış ortamdan içeriye hava transferi yapabilen, iç ortamdaki havayı da dışarı verebilen ve iklim kontrolü (ısıtmasoğutma-nem) ile havalandırmayı aynı anda yapabilen sistemlerin kliniklere kurulması ve periyodik bakımlarının yapılmasının önemi açıktır.

\section{SONUÇ}

Prostodonti kliniğinden akşam ve sabah ölçümlerinde havalandırma sisteminin açık ve kapalı olduğu durum için hem bakteri hem de mantar sayıları arasında istatistiksel olarak anlamlı ölçüde değişim gözlenmiştir. Çalışmadan elde ettiğimiz verilere göre klinik havalandırma- klima sisteminin bakterial- fungal kolonizasyonu azaltacağı hipotezi kabul edilmiştir. 


\section{KAYNAKLAR}

1. Checchi L, Matarasso S, Pirro P, D'Archille C. Topographical analysis of the facial areas most susceptible to infection with transmissible diseases in dentist. Int J Periodontics Restorative Dent, 1991; 11: 164-72.

2. Kedjarune $U$, Kukiattrakoon B, Yapong B, Chowanadisai S, Leggat PA. Bacterial aerosols in the dental clinic: effect of position, time and type of treatment. Int Dent J 2000; 50: 103-7.

3. Gürgan S, Köprülü H, Alaçam R. Kavite preparasyonu sırasında oluşan bakteriyel kontaminasyonlar. Hacettepe Diş Hekimliği Fakültesi Dergisi 2002; 12: 458.

4. Teanpaisan $R$, Teaporamaysamai $M$, Rattanachone $P$, Poldoung $\mathrm{N}$, Srisintorn $\mathrm{S}$. The usefulness of the modified extra oral vacuum aspirator (EOVA) from house hold vacuum cleaner in reducing bacteria in dental aerosols. Int Dent J 2001; 51: 413-6.

5. Fiehn NE, Larsen $T$. The effect of drying dental unit waterline biofilms on the bacterial load of dental unit water. Int Dent J 2002; 52: 251-4.

6. Taşar F, Tümer C. Viral Hepatit ve Diş Hekimliği. Hacettepe Diş Hekimliği Fakültesi Dergisi 1991; 1-4: 81 4.

7. Kayalıbay $H$, Uzamış M, Akbulut E. Diş Hekimliğinde Enfeksiyon Kontrolü. Hacettepe Diş Hekimliği Fakültesi Dergisi 1994; 18: 6-8.

8. Özperk G, Akın L. Diş Hekimliğinde Çapraz Enfeksiyon ve Korunma Yolları. Hacettepe Diş Hekimliği Fakültesi Dergisi 1994; 15: 119-22.

9. Yenisey M. Prostodonti Pratiğinde Çapraz Kontaminasyonun Önlenmesi. Ondokuz Mayıs Dişhek Fak Derg 2000; 3: 42-51.

10. Kalogerakis N, Paschali D, Lekaditis V, Pantidou A, Eleftheriadis K, Lazaridis $M$. Indoor air qualitybioaerosol measurements. J Aerosol Sci 2005; 36: 75161.

11.Kadaifciler DG, Ökten S, Sen B. Mycological contamination in dental unit waterlines in Istanbul, Turkey. Braz. J. Microbiol 2013; 44: 977-81.

12. Kadaifciler DG, Güngör ND, Cotuk A. Opportunistic bacterial pathogens of aerosol and water samples from dental equipments. Fresenius Environ Bull 2015; 24.2 A: 610-4.

13. Konieczny P, Cegielska-Radziejewska R, Mroczek E, Dziedzic J. Analysis of air quality in selected areas of a poultry processing plant with the use of a microbiological air sampler. Rev Brasileira Ciencia Avícola 2016; 18: 401-6.

14. Cabbay J, Bergerson O, Levi N, Brenner S, Eli I. Effect of ionization on microbial air pollution in the dental clinic. Environ Res 1990; 52: 99- 106.

15.Merck, MAS- 100 Microbiological Air Sampler Operator's Manual 1999.

16.Jensen PA, Schafer MP. Sampling and Characterization of Bioaerosols, NIOSH Manual of Analytical Methods 1998.
17.Labaf H, Owlia P, Taherian A, Haghgoo R. Quantitative analysis of changes in bacterial aerosols during endodontic, periodontic and prosthodontic treatments. Afr J Mic Res 2011; 5: 4546-8.

18.Barlean L, lancu LS, Minea ML, Danila I, Baciu D. Airborne microbial contamination in dental practices in lasi, Romania. OHDMBSC 2010; 9: 16-20.

19.Grenier D. Quantitative analysis of bacterial aerosols in two different dental clinic environments. Appl Environ Microbiol 1995; 61: 3165-8.

20. Leggat $P$, Kedjarune $U$. Bacterial aerosols in the dental clinic: a review. Int Dent J 2001; 51: 3944.

21. Helmis CG, Tzoutzas J, Flocas HA, Halios CH, Stathopoulou OI, Assimakopoulos VD, Panis V, Apostolatou M, Sgouros G, Adam E. Indoor air quality in a dentistry clinic. Sci Total Environ 2007; 377: 349-55.

22. Polednik B. Aerosol and bioaerosol particles in a dental office. Environ Res 2014; 134: 405-9.

23. Totaro M, Costa AL, Casini B, Profeti S, Gallo A, Frendo L, Porretta A, Valentini P, Privitera G and Baggiani A. Microbiological Air Quality in Heating, Ventilation and Air Conditioning Systems of Surgical and Intensive Care Areas: The Application of a Disinfection Procedure for Dehumidification Devices. Pathogens 2019; 8: 8-16.

24. Elnour AA, Abdelfattah MM. Negm $S$ and Kassim T. Microbiological Surveillance of Air Quality: A comparative Study Using Active and Passive Methods in Operative Theater. International Journal of Pharmaceutical and Phytopharmacological Research 2018; 8: 33-8.

25. Monteiro PM, Carvalho A, Pina C, Oliveira H, Conceic M. Air quality assessment during dental practice: Aerosols bacterial counts in an universitary clinic. Revista Port Estomatol Med Dent Cir Maxilofac. 2013; 54: 2-7.

\section{Yazışma Adresi:}

Murat YENISEY

Ondokuz Mayıs Üniversitesi

Diş Hekimliği Fakültesi

Protetik Diş Tedavisi Ana Bilim Dalı

Kurupelit Yerleşkesi 55139 Atakum, Samsun

Tel : : +903623121919/3049

Gsm : +90 5324929076

Faks : +90362 4576032

e-Posta: muratyen@omu.edu.tr 